\title{
Refuge
}

Canada's Journal on Refugees

revue canadienne sur les réfugiés

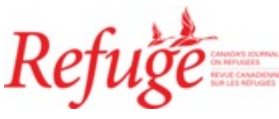

\section{Queer Credibility in the Homonation-State: Interrogating the Affective Impacts of Credibility Assessments on Racialized Sexual Minority Refugee Claimants}

\section{Jen Rinaldi and Shanti Fernando}

Volume 35, Number 1, 2019

Racialized Refuge

URI: https://id.erudit.org/iderudit/1060673ar

DOI: https://doi.org/10.7202/1060673ar

See table of contents

Publisher(s)

Centre for Refugee Studies, York University

ISSN

0229-5113 (print)

1920-7336 (digital)

Explore this journal

Cite this article

Rinaldi, J. \& Fernando, S. (2019). Queer Credibility in the Homonation-State: Interrogating the Affective Impacts of Credibility Assessments on Racialized Sexual Minority Refugee Claimants. Refuge, 35(1), 32-42.

https://doi.org/10.7202/1060673ar
Article abstract

This article critically appraises Canadian Immigration and Refugee Board decision-making that imposes burdens on diverse sexual orientation and gender identity and expression refugee claimants of colour to prove that they are queer according to homonationalist interpretations of queerness. This article examines decisions clustered around historical developments in the reception of racialized sexual minorities, including Canada (AG) v Ward, which made sexual minority refugee claims possible; Bill C-31, the immigration and refugee policy motivated by national security interests in the post-9/11 era; and 2017 guidelines designed to dispel misunderstandings about refugee claimants' sexuality. Across this history, credibility assessments of refugee claims have undergone significant recalibrations, yet continue to reflect homonationalist values.
Copyright (c) Refuge: Canada's Journal on Refugees, 2019

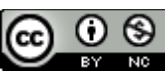

This document is protected by copyright law. Use of the services of Érudit (including reproduction) is subject to its terms and conditions, which can be viewed online.

https://apropos.erudit.org/en/users/policy-on-use/ 


\title{
Queer Credibility in the Homonation-
} State: Interrogating the Affective Impacts of Credibility Assessments on Racialized Sexual Minority Refugee Claimants

\author{
JEN RINALDI AND SHANTI FERNANDO
}

\section{Abstract}

This article critically appraises Canadian Immigration and Refugee Board decision-making that imposes burdens on diverse sexual orientation and gender identity and expression refugee claimants of colour to prove that they are queer according to homonationalist interpretations of queerness. This article examines decisions clustered around historical developments in the reception of racialized sexual minorities, including Canada (AG) v Ward, which made sexual minority refugee claims possible; Bill C-31, the immigration and refugee policy motivated by national security interests in the post-9/11 era; and 2017 guidelines designed to dispel misunderstandings about refugee claimants' sexuality. Across this history, credibility assessments of refugee claims have undergone significant recalibrations, yet continue to reflect homonationalist values.

\section{Résumé}

Cet article évalue de façon critique la manière dont le processus de décision de la Commission de l'immigration et du statut de réfugié du Canada impose aux demandeurs d'asile d'orientations sexuelles et d'identités ou d'expressions de genre diverses le fardeau de prouver qu'ils sont queer en vertu d'interprétations homonationalistes. Larticle examine des décisions regroupées autour de développements historiques dans la réception des minorités sexuelles racialisées, dont Canada (Procureur général) c. Ward, qui a rendu possible les demandes d'asile sur la base de l'appartenance à une minorité sexuelle; le Projet de loi C-31, politique d'immigration et d'asile motivée par des intérêts de sécurité nationale dans lère post-11-septembre; et les directives de 2017 conçues pour dissiper les malentendus concernant la sexualité des demandeurs d'asile. Bien quayant subi des ajustements importants à travers l'histoire, l'évaluation de
() Jen Rinaldi and Shanti Fernando, 2019. This open-access work is licensed under a Creative Commons Attribution-NonCommercial 4.o International Licence, which permits use, reproduction, and distribution in any medium for non-commercial purposes, provided the original authorship is credited and the original publication in Refuge: Canada's Journal on Refugees is cited.
Cette ouvre en libre accès fait l'objet d'une licence Creative Commons Attribution-NonCommercial 4.o International License, laquelle autorise l'utilisation, la reproduction et la distribution de l'œuvre sur tout support à des fins non commerciales, pourvu que l'auteur ou les auteurs originaux soient mentionnés et que la publication originale dans Refuge: revue canadienne sur les réfugiés soit citée. 
la crédibilité des demandes d'asile continue de refléter des valeurs homonationalistes.

\section{Introduction}

T $\mathrm{n}$ this article we critically appraise Canadian Immigration and Refugee Board (IRB) decision-making that imposed 1 burdens on diverse sexual orientation and gender identity and expression (SOGIE) refugee claimants of colour to prove that they are queer according to homonationalist interpretations of queerness. ${ }^{1}$ We interrogate legal discourses on "authentic queer refugeeness," an attribute attached to persons who are socially, politically, and legally organized in ways that force them to conform to white Western ideals. ${ }^{2}$ Belying this identity are settler colonial, white supremacist interpretations of belonging to Canadian LGB community. ${ }^{3}$ Through an analysis of Canadian jurisprudence, we show that an undue burden is placed on queer refugee claimants of colour when homonationalist scripts inform IRB decisionmaking on the credibility of their claims. ${ }^{4}$

Coined by Jasbir Puar, the term homonationalism refers to a nationally recognized version of homosexuality, predicated on "the segregation and disqualification of racial and sexual others from the national imaginary." Homonationalism sits at the root of legal and political processes by which a nationalist agenda defines and imposes narrow definitions of queerness for its citizenry. The application of the construct of homonationalism to the history of Canada's refugee system has a place in emergent socio-legal scholarship. As David Murray argues, "The refugee apparatus is contributing to the production of a new permutation of homonationalism, a highly delimited and normative narrative of same-sex sexual citizenship and national belonging, which now includes some migrant bodies, but excludes many others." This permutation underscores the narratives queer refugee claimants must enact in order to qualify for refugee protection. Hegemonic SOGIE refugee narratives inform credibility assessments in IRB contexts. This means that claims to queerness that do not meet nationally recognized definitions of queerness are associated with fraud in IRB determinations. ${ }^{7}$ While this analysis could apply to the range of diverse SOGIE representation, our focus will be on sexuality or sexual orientation-gay, lesbian, and bisexual persons-with the acknowledgement that persons with diverse gender identities and expressions-trans ${ }^{*}$, genderqueer, and gender-neutral folk-face complex and unique challenges in relation to racialization and refugeeness that are beyond the scope of this article. We explicitly acknowledge that gender identity and expression constitute a critical area of inquiry for future research and should be addressed and affirmed in refugee frameworks.

We extend our analysis by returning to Puar's original application of homonationalism: to post-9/11 North
American politics. For Puar, "during this historical juncture, there is a very specific production of terrorist bodies against properly queer subjects." ${ }^{8}$ The incommensurability of these subject states rests on an envisioning of queerness informed by "conservative homonormative ideologies and queer liberalism."' Canada's refugee system deals in queer exclusions, evidenced by IRB decision-making, especially in the post-9/11 era. Since the 2001 airplane hijackings and attacks on the us Pentagon and World Trade Center, nationstates including Canada have exhibited increasing suspicion toward racialized subjects-including and especially refugees-borne out in regulation, securitization, and policing. Homonationalism complicates constructions of refugeeness, and constructs of The Refugee are considerably distanced from the reality that refugees experience: refugees, and in particular sexuality minority refugees, are vulnerable and fleeing trauma, and should be supported rather than feared.

Through this lens of homonationalism, we examine decisions rendered by IRBS and on appeal, clustered around historical developments in the reception of racialized sexual minorities. Specifically, we first consider decisions following the establishment of sexual minorities as a special group entitled to protection from persecution under domestic refugee law, as determined in the 1993 decision Canada ( $A G$ ) $v$ Ward. ${ }^{10}$ Next, we analyze decisions following Bill C-31, the immigration and refugee policy motivated by national security interests in the post-9/11 era. ${ }^{11}$ Finally, we investigate decisions that were required to incorporate 2017 guidelines designed to dispel misunderstandings about diverse SOGIE refugee claimants. ${ }^{12}$ Across this history, credibility assessments of refugee claims have undergone significant recalibrations. In this article we evaluate whether and to what extent IRB discourses, so recalibrated in these three historical moments, consistently reflect homonationalist values. In particular, jurisprudence since the Ward decision has included patterns of credibility assessments that reflect narrowly conceived forms of queer liberation-gendered aesthetics, participating in LGB culture, disavowal of traditional cultural values - that may not be accessible or known to racialized refugees. The discursive analysis in this article highlights how IRBS act as gatekeepers and keep that gate shut on the basis of homonationalist standards of queer expression.

\section{Connecting Homonationalism to Canadian Refugeeness}

Puar's concept of homonationalism entails biopolitical arrangements that uphold a nationally acceptable or respectable queer identity. Those sexual minorities who receive national recognition must express queerness in ways that signal a "turn toward life." Put another way, "By regularizing 
queerness, [heteronationalist discourse] patrols the boundaries between queer subjects who are invited into life and queer populations who come into being through their perverse sexual-racial attributes and histories." ${ }^{13}$ For instance, they must avoid sex work, bathhouses, and an HIV/AIDs diagnosis. ${ }^{14}$ A properly queer subject must also turn toward the perpetuation of life by, as examples, seeking same-sex marriage, making use of reproductive technologies or adoption services to build families, and contributing to the revitalization of their communities. The problem is not the elements themselves, but that these elements become the only acceptable way of being queer. In other words, sexual citizenship tends to be more accessible to these expressions of queerness, and closed off to subversive or subaltern expressions. ${ }^{15}$ The parameters to citizenship can be construed broadly in terms of national belonging, such that citizens are constituted as such by legal, political, and cultural practice. One comes to be a citizen-or more precisely in this context, one is welcomed into the nation-when normalized through the discourses of a polity. Sexual minorities are policed and produced in order to belong to a body politic, and are excluded from that body politic when they are too subversive. Sexual minority refugees are considered both subversive, as potential security threats, and liminal, given that they are in political and legal limbo. This makes their position all the more precarious, as they have the subjective construction of their refugeeness coupled with homonationalist expectation.

How does the intersection of sexual and racial histories come to signify the perverse? Subtending the properly queer figure of homonationalist discourses are interlocking systems of oppression at the core of the Canadian state, in particular settler colonization and white supremacy. In Puar's words, "The ascendancy of whiteness and the ascendancy of heteronorms are biopolitical comrades." ${ }^{16}$ The queer liberation available through homonationalist biopolitics is available only to subjects with racial privilege. Those queer subjects too subversive, or even not queer enough, to achieve national belonging enact a queerness that falls outside the bounds of white liberal identity work. When considering Puar's theorizing on homonationalism, Sara Ahmed argues, "Racism saturates everyday and institutional spaces," which affectively renders an ethnic minority "out of place." ${ }^{7}$

Homonationalism, then, affects queer subjects, and in particular queer refugees, in two ways. First, when LGB membership is so heavily policed, those queer folk who live on the fringes of membership, or whose practices do not signal a turn toward life, are excluded or discounted. They are regarded and treated as not properly queer, or as an embarrassment to the queer community. To coin a phrase used by Sara Ahmed, they are "out of place," insofar as they do not belong to Canadian queer communities. ${ }^{18}$ In the context of
IRB decision-making, claimants who fail to enact acceptable forms of queerness are not granted refugee status, so they are excluded and excised from the body politic altogether. Second, sexual minority claimants come to perform particular versions of sexual identity in order to satisfy an Immigration and Refugee Board that has constructed Canadian refugeeness along homonationalist lines. Their negotiation of legal process produces narrow forms of queerness. ${ }^{19}$ Therefore IRBS as homonationalist instruments produce the categories of sexual citizenship that qualify for state protection. ${ }^{20}$ As we go on to demonstrate, the failure of some claimants, and the success of others at the cost of having their identities policed, are racially inflected. As Lacroix has argued, "Refugeeness emerges then as a way of understanding the particular subjective experience [of refugees] in relation to existing refugee policies." ${ }^{21}$ These policies derive from legal, political, and social frameworks that reflect sexual and racial bias.

Homonationalism also affects the nation-state in two directions. First, the nation is constituted by successful claimants, meaning that LGB representation stagnates in the national landscape. Canada's concept of homosexuality, in other words, becomes a homogenous one. ${ }^{22}$ Second, homonationalist discourses trigger the narrative of the saviour state, where the emphasis in refugee determinations is not on how racialized queer folk are cast off but that any queer folk at all are brought in. Homonationalism, therefore, facilitates the narrative that Canada is an inclusive, tolerant, welcoming place for queer subjects, especially compared to non-white countries. Ahmed asks us to be wary of discourses that emphasize a nation's sexual freedom, which "can be mobilized in the war on terror, and can be used to justify the extension of state racism." ${ }^{23}$ Through homonationalist arrangements, the Canadian nation-state claims sexual liberation as a defining attribute, in opposition to non-white, non-Western states that are characterized as sexually repressive.

In what follows, we present analysis of selected cases where an IRB questioned a refugee claim on the basis of the credibility of the claimant's sexual minority membership. The record we present cannot guarantee to feature persons of colour, given that this information is not explicitly identified in the text of IRB decisions and there is no systematized analysis of the jurisprudence on racial grounds. What we have done instead is examine decisions featuring refugee claimants whose countries of reference have predominantly non-white populations. These countries carry ethnic or cultural histories, values, and practices that contribute to more complex and diverse iterations of sexuality. Insofar as refugee claimants come from a country that is predominantly non-white, their enactments of sexuality may be incommensurate with Canada's understanding of sexuality. So regardless of how claimants' bodies are read, regardless of whether they are a visible black or brown 
minority, they are racialized when their version of sexualitya version that evolved from predominantly non-white cultural traditions-is ruled inauthentic.

We also present a mixed record on how the undue burden of sexual minority authentication operates as a norm in refugee law. Canada's refugee system has mechanisms to catch when decisions reflect bias, as evidenced when IRB decisions are scrutinized at the Federal Court (FC) level. IRB decisions have been overturned for relying on stereotype, and the FC has explicitly stated that refugee status applications cannot be determined on the basis of stereotype. ${ }^{24}$ While appellate bodies have served as a check on the IRB, appeals are not a viable option for all sexual minority refugee claimants, nor should that be their recourse to access justice; they should simply not be failed at the IRB level. As noted in the literature, "While the Federal Court has made these issues jurisprudentially clear, the volume, [and] repetition ... of this jurisprudence indicate the difficulty first-level decision makers continue to have adjudicating [LGB] asylum claims." ${ }^{25}$ Further, initial decisions-even the ones overturned-do affective work. As long as stereotypes continue to creep in, they affect queer enactments and conceptualizations of the nation-state. As Ahmed articulates, "Words can indeed be affective; a mere proximity between words can make danger an essential quality of others." ${ }^{36}$ In that spirit, one where we are interested in the affective implications of legal discourse, we explore select examples where we see that the success of a diverse SOGIE refugee claimant is predicated at least initially on imagined whiteness, or affinity for Canadian queer culture that presents as white and is made for white subjects. The first era we turn to is the Ward decision, which opened the door to queer refugee protection, but also launched the ascendance of queer credibility. ${ }^{27}$

\section{The Ward Decision: The Ascendance of Queer Credibility}

Refugee law first recognized sexual minorities as members of a social group that could have a well-founded fear of persecution in 1990s-era jurisprudence. ${ }^{28}$ In the 1991 case Re $N$. (K.U.), the IRB granted asylum to a gay man who feared persecution for identifying as a homosexual in his country of reference, Bangladesh. ${ }^{29}$ Following this case, the identification of diverse sogIE refugees as members of a social group was formalized in the obiter dictum of the 1993 Supreme Court of Canada (SCC) decision Canada (AG) $v$ Ward, which itself did not directly pertain to diverse sogIE refugees. ${ }^{30}$ Through the course of his reasoning for a unanimous judgment, Justice Gerard La Forest took the opportunity to define social group under refugee law. The definition is threefold: (1) "groups defined by an innate, unchangeable characteristic"; (2) groups consisting in members who associate for reasons so fundamental to their human dignity that forcing them to forsake association is out of the question; and (3) groups that might have originally been based on voluntary membership but became historically permanent. ${ }^{31}$ As stipulated in the decision, "The first category would embrace individuals fearing persecution on such bases as gender, linguistic background and sexual orientation." ${ }^{32}$

Subsequent IRBs complied with the Ward ruling, adopting in their decisions the scc's definition of a social group. ${ }^{33}$ Ward paved the way for refugee claims based on sexual orientation, provided the claimant could prove membership. IRBS, then, incorporated into decisions on sexual minority refugee applications proof of social group membership. This additional expectation of claimants meant that a portion of claim determination turned on credibility - not just that the claimant was an authentic refugee, but that the claimant was authentically queer. The regime established for sexual minority refugee claims has posed complications for determining credibility. Nicholas Hersh argues that in the absence of formalized rules for what constitutes proof of social group membership, "adjudicators sometimes impose burdensome and unfair expectations on claimants to prove their sexual orientation when soliciting refugee status." ${ }^{34}$ Homonationalist narratives underpin many of the most egregious expectations in credibility determinations. Specifically, Sharalyn Jordan and Chris Morrissey describe these trends: "Decisionmakers rely on their own background knowledge-often based on culturally constrained understandings of sexualities and genders - to assess the credibility of an applicant's identity claim." ${ }^{35}$

Constrained IRB understandings of sexuality pose unique challenges for racialized persons. There are instances of IRB decision-makers assuming that queer folk modulate their appearance to match a specific aesthetic, most evident in butch lesbians or effeminate gay men. According to United Nations High Commissioner for Refugees Guidelines, "A person cannot be denied refugee status based on a requirement that they change or conceal their identity, opinions or characteristics in order to avoid persecution." ${ }^{36}$ In other words, that refugee claimants did not enact recognizable forms of queerness in their country of reference cannot count as grounds for questioning the credibility of their sexuality. Nevertheless, there have been IRB decisions that have presumed claimants would modify their appearance to express familiar forms of queerness after living in Canada long enough. The presumption was that Canada is a safe place for queer expression-recognizable kinds of queer expression at that-so there should no longer be reason to conceal identity, opinions, or characteristics.

For example, in Herrera $v$ Canada (Minister of Citizenship and Immigration), the FC overturned an IRB decision 
for exhibiting bias-or a "thoroughly discredited stereotype which should not have any bearing on the Board's judgment of the Applicant's credibility"-when rejecting a refugee application. ${ }^{37}$ The applicant, Oscar Marquez Herrera, claimed he was rejected by his family and employers, and subjected to physical and verbal violence in Mexico for being a gay man. ${ }^{38}$ The original reasoning for rejecting his refugee application included his lack of an "allure efféminée," or effeminate appearance. ${ }^{39}$ The FC found the reasoning "particularly astonishing on the part of a decisionmaker who is in a position to adjudicate sensitive claims that could be expected to involve homosexuality" ${ }^{\prime 0}$ The decision was sent back for redetermination before a different IRB on the grounds that the original board breached "both a principle of natural justice and procedural fairness" and made "unreasonable and erroneous findings of fact." ${ }^{\text {"1 }}$

Further, there are instances in the jurisprudence where claimants are expected to narratively distance themselvestheir identity, values, and motivations-from their country of reference, and demonstrate that their liberation involves incorporation into Canadian queer cultures and contexts. In Dosmakova $v$ Canada (Minister of Citizenship and Immigration), Sofya Dosmakova of Kazakhstan applied for refugee protection on the grounds of religion and sexual orientation. She explained she had begun a romantic relationship with a female friend at the age of fifty-six and consequently had encountered beatings and police intimidation. When asked in her IRB hearing about her sexuality, she testified that she felt "happiness and sexually satisfied ... and had no regrets." ${ }^{42}$ The board did not find this answer credible, because she should have felt inner turmoil about her sexuality while living in a country of reference that subjected her to persecution. In other words, Dosmakova should have felt alienated and ashamed in Kazakhstan if she really were a lesbian. Her application was originally rejected, until the FC remitted her application for redetermination by a different board.

These examples illustrate that there is a very specific set of behaviours that IRBs have presumed reflect proper or authentic queerness. While Ward signalled a legal victory for sexual minority refugees, its strings attached-credibility jurisprudence-carried implications into post-9/11 securitization strategies. Constructions of refugeeness, and their reliance on credibility determinations, were further reshaped through immigration and refugee policy. This fundamentally changed the Ward decision's impact on sexual minority refugee claimants.

\section{Legislative Reform in the 9/11 Turn: The Securitization of Refugees}

The credibility of refugee claims came under renewed scrutiny in the post-9/11 world. In 2001, shortly before (though since interpreted through the lens of) the September 11 airplane hijackings and attacks on the us Pentagon and World Trade Center, Canada's immigration and refugee system was overhauled with the passing of Bill C-11, the Immigration and Refugee Protection Act (IRPA). ${ }^{43}$ This policy, and the political discourse it generated, would come to represent a turn in the underlying premise of refugee acceptance, where refugees came to be regarded and treated as much greater security risks. Gradually a securitization agenda emerged in Canada, intensified following large-scale terrorist attacks on North American soil perpetrated by non-white persons. A securitization paradigm gave authorities further incentive to make policies against unwanted migrants much harsher: "Securitization as a process means that the spheres of internal and external security are merging after a period of polarization in which those two areas of activity had hardly anything in common. We have witnessed a change in perspective: states-and specifically their external security agencies, which traditionally worked against a foreign enemy-have identified new threats, such as terrorism, international criminality and unemployment, which coalesce in the image of the migrant." ${ }^{44}$

The IRPA was described and deployed as a "protection" act; it organized the government as a protector of Canadians from the potential threats of immigrants and refugees. Under article 3(2), policy objectives include " $(\mathrm{g})$ to protect the health and safety of Canadians and to maintain the security of Canadian society; and (h) to promote international justice and security by denying access to Canadian territory to persons, including refugee claimants, who are security risks or serious criminals." ${ }^{45}$

While these policy developments operated separate from the Ward decision, and the identification of sexual minorities as a social group under refugee law as established in Ward remains intact, the IRPA has had an impact on the status of racialized sexual minority refugee claimants. Their credibility is questioned more vigorously, and this has changed how the precedent established through Ward operates. Therefore, relying on the Ward decision to protect sexual minorities ignores the fact that the 1993 decision occurred in a pre-9/11 context, and our national landscape since $9 / 11$ has rendered the position of all racialized refugees, including sexual minorities, much more precarious.

Canada's refugee apparatus saw its next significant reform following a federal election that resulted in a Conservative majority government. Bill C-31 was tabled in 2011, received royal assent in June 2012, and came into force as the Protecting Canada's Immigration System Act in December 2012. ${ }^{46}$ The Immigration and Refugee Board of Canada has described this legislative reform as "one of the most significant transformations in its history." ${ }^{47}$ Jason Kenney (at the time the 
federal minister of citizenship, immigration and multiculturalism), along with his political party (the Conservative Party, holding a majority government at the time), claimed that the bill was meant to solve backlog due to fraudulent claims: "The system is clogged with false applications." 48

The law dramatically amended the Immigration and Refugee Protection Act and the Balanced Refugee Reform Act, for the purpose of "provid[ing] for the expediting of the processing of refugee protection claims." 49 As described, "The new regime entails a swath of measures that aim to 'crack down' [in ways that] seriously erode the protection imperative in domestic and international law." ${ }^{50}$ In particular, the refugee claims process was expedited by introducing new qualification and appointment standards for IRB decision-makers, rendering the deportation process more efficient, and denying appeal measures to particular refugee categories. With compressed timelines for refugee status determination, pressure on sexual minority refugee claimants was increased to produce evidence of queer membership-evidence of relationships, cultural participation, and group affiliation claimants now lack time to develop..$^{51}$ Jordan and Morrissey concur: "Under the new system applicants simply will not have time to connect with [LGB] communities or organizations." 52

Further, with legislative reform the figure of the refugee was set in even sharper relief against the figure of the criminal, or the threat to national security. Definitions of criminality as grounds for denying refugee status were expanded under the new legal measures, dropping the requirement that serious criminals must pose a public danger in order for their refugee claim to be denied. Bill C-31 additionally introduced mandatory detention and stricter rules for irregular entry (e.g., boat arrivals, safe country provisions) and the removal of permanent residents who lose their protected status. ${ }^{53}$ According to Kathryn Trevenen and Alexa Degagne, legislation organized in response to the spectre of the "bogus refugee" concretizes hegemonic racial divides and the national mythologies built along those divides: "The idea that there are hordes of (deceptive and greedy) 'bogus refugees' seeking to take advantage of the (generous and fair) Canadian immigration system works to justify increased surveillance, regulation, and refusal of refugee claimants. The 'bogus refugee' thus joins the 'queue jumpers,' 'the terrorists', and the 'dependents'-racialized figures, positioned as threatening, who wait at Canadian borders, looking for a gap in security or an excess of the mythological Canadian softheartedness." ${ }^{54}$

These dividing lines drawn between the problematized racial figure and the nation-state exploring its limits of liberal tolerance "depend on complex processes of both queering and racializing to make the divisions between worthy citizens and excluded 'others." ${ }^{\text {"55 }}$ While the security apparatuses developed in refugee law do not explicitly work to exclude racialized sexual minorities, they nevertheless reinforce the entrenched paradigms that subtend diverse sOGIE credibility determinations. ${ }^{56}$ Legislation like Bill C-31 engenders a "problematic proximity" between refugees and fraud. ${ }^{57}$ In contexts saturated with racism, this proximity is exacerbated when the refugee claimant's country of reference is racialized and associated with terrorist activity.

Claimant testimony entered as evidence may include knowledge of and involvement in queer culture (without the acknowledgement that queer culture is regionally specific), including Pride events and popular Canadian LGB bars, social establishments, and/or advocacy groups. The expectation of engagement in and knowledge of explicitly LGB spaces in Canada presupposes that these spaces are welcoming, accessible, and desirable for queers of colour. Further, the expectation of "giving back" through advocacy presumes the queer subject embraces, and has the wherewithal to enact, civic engagement. For example, the FC overturned the decision originally rendered in Essa $v$ Canada (Minister of Citizenship and Immigration) for expecting the applicant to know and frequent Montreal's gay neighbourhood, a presumption the FC deemed "stereotypical and unreasonable."58 The applicant, Mohammad Essa, alleged that in his country of reference, Jordan, his uncle discovered him in a compromising situation with his male partner and beat him. ${ }^{59}$ His uncle also subsequently sought a fatwa in order to have Essa killed. ${ }^{60}$ The applicant admitted ignorance about LGB culture in Quebec, claiming he was discrete about his sexuality. In his own words, "To be honest with you the way I'm living my life here is not the way that the gay community here is." ${ }^{\prime 1}$ The IRB concluded that he was not gay as a result of his "reticence ... to explore behaviour that is often characteristic of the gay community." ${ }^{\text {2 }}$ The FC found this reasoning stereotypical and unreasonable, and there was no need to address this aspect of Essa's credibility. ${ }^{63}$

Similarly, in Buwu v Canada (Minister of Citizenship and Immigration), a Nigerian refugee claimant from Zimbabwe was initially rejected for, among other reasons, lacking familiarity with Canadian lesbian establishments. ${ }^{64}$ Anesu Buwu claimed she was physically attacked by her parents and brother when she disclosed her sexuality, her father threatening to kill her as she escaped. ${ }^{65}$ Among other reasons, her credibility was questioned because "the claimant was not able to express ... as to how she is living openly here in Canada." ${ }^{\prime 66}$ On appeal, the original decision-making body was critiqued for relying on "personal and extrinsic knowledge that is never put to the Applicant." ${ }^{\prime 7}$ These examples follow board decisions along lines of logic that expect claimants to distance themselves from their problematized countries 
of reference and immerse themselves in liberatory Canadian culture. Authentic queerness thus requires a disavowal of terrorist proximities.

In response to the issues raised in post-Ward, post-9/11 IRB decisions, there was an attempt to regulate board encounters with refugees in order to ensure the decision-making did not rely on stereotypes. Guidelines developed in 2017 to regulate refugee decision-making acknowledge that IRBs should allow for diverse expressions of queerness, and direct adjudicators to consider the harm experienced by those who do not comply with hegemonic sogIE norms. These guidelines offer progress for sexual minority refugees, but their identification of the longstanding problem of entrenched prejudice signals a need for sustained vigilance in regulating the IRB encounter.

\section{The Chairperson's Guidelines: Regulating the IRB Encounter}

In May 2017 the chairperson of the Immigration and Refugee Board issued guideline 9, "Proceedings before the IRB Involving Sexual Orientation and Gender Identity and Expression," to address stereotype associated with diverse SOGIE refugee claimants. Its purpose as stated is "to promote greater understanding of cases involving [SOGIE] and the harm individuals may face due to their nonconformity with socially accepted SOGIE norms." ${ }^{38}$ Under section 3.1, the guidelines acknowledge, "Depending on factors such as race, ethnicity, religion, faith or belief system, age, disability, health status, social class and education, individuals with diverse sogIE recognize and act on their SOGIE differently." ${ }^{\prime 69}$ This intersectional analysis also entails recognition that the harms experienced by diverse sogIE refugees may be compounded and unique as the result of the confluence of racial or ethnic identity. ${ }^{70}$

Decision-makers in refugee law are advised not to rely on stereotype associated with diverse SOGIE, including instances that have surfaced through the history of hearings: "Individuals with diverse sogIE have feminized or masculinized appearances or mannerisms"; "Individuals with diverse SOGIE do not participate in cultural or religious customs or traditions"; "Individuals with diverse sogIE would not voluntarily enter a heterosexual marriage or have children., ${ }^{11}$ While evidence of community engagement is not discounted, the Chairperson's Guidelines warn, "An individual with diverse SOGIE may not have participated in LGBTIQ+ culture, organizations or events in their country of reference, nor do so once in Canada." 72 Decision-makers are further advised to be "careful that the inconsistencies [in testimony] are not based on stereotype or inappropriate assumptions." ${ }^{73}$

The guidelines should be a promising development in refugee law. If the Ward decision had the problematic implication that sexual minority status would become a site of scrutiny in credibility assessments without concrete standards for assessment, and legislation in the 9/11 turn intensified credibility assessments and the driving narrative that refugee applicants are testing Canadian liberal tolerance with fraudulent claims, then the guidelines are designed to be a corrective to how credibility assessments are handled in diverse SOGIE cases. Subsequent decisions at the IRB level involving diverse sogIE refugee claimants acknowledge that the Chairperson's Guidelines must factor into decisionmaking. In this new era for sexual minority credibility assessments, the effectiveness of the guidelines should be measured according to whether they prevent homonationalist scripts. Their value has been that they redress decisions that, despite being undone, nevertheless contribute to constructions of the refugee, of the authentic queer, and of the overlap they share.

Consider the policy's approach to vague testimony, under section 7.6.1: "Testimony about same-sex relationships that is vague and lacking in detail may support a negative credibility inference; however, decisionmakers should examine whether there are cultural, psychological or other barriers that may explain the manner in which the testimony is delivered." ${ }^{74}$ In a $2017 X(R e)$ hearing, the IRB found a decision made by the Refugee Protection Division (RPD) applied legal reasoning that was not aligned with the Chairperson's Guidelines. The case referenced involved a Sri Lankan citizen who applied for refugee status on the grounds that he "may be assaulted by members of extremist groups or the general public, or arrested by the police for being a homosexual." ${ }^{75}$ According to the Board hearing his claim, "The RPD erred in its zeal to find weaknesses in the Appellant's testimony," because while the claimant's answers were imprecise, "the RPD failed to give due consideration to the trauma experienced by the Appellant as a result of hiding and denying his sexual orientation for decades." 76 This analysis of the original decision was rooted in Nicholas Hersh's observation that testimony delivered by sexual minority refugee claimants may be vague or partial as the result of stigma, trauma, and internalized homophobia. ${ }^{77}$ What has been bracketed out of the problem of vagueness, however, is the possibility that the queerness the claimant enacted was shaped by non-traumatic experiences in his country of reference. Interpretation of the cultural barrier in this decision was predicated on there being oppressive conditions in Sri Lanka. This observation is not meant to undermine the debilitating conditions faced by sexual minorities around the world, nor does it presume a refugee hearing should avoid engaging with those conditions-after all, the strength of a SOGIE claim is predicated on an inability or an unwillingness to return for fear of persecution. Our point here is, first, that the interpretation of cultural barriers offered in this case-particularly its attachment 
to trauma-is insufficiently narrow if the issue at stake is whether the claimant is credibly gay. Further, the structuring of legal decision-making, regardless of its inevitability, does affective work to constitute the receiving nation-state as liberal, against a country of reference that is not.

The question of cultural variation plays out elsewhere in the jurisprudence. In another hearing titled $X(R e)$ from 2017, this time involving a bisexual Nigerian man, his credibility was found suspect on a number of grounds. ${ }^{78}$ Among them, the RPD doubted that the claimant would be ignorant of details involving his same-sex partner, with whom he was having an eighteen-year-long affair-details such as his partner's romantic preferences. On this count the IRB found that "the RPD looked at the issue through a 'Western lens' and did not have regard for the Appellant's culture and background, according to which one would not openly communicate information regarding one's sexuality." ${ }^{\text {"9 }}$ But beyond this, the IRB examined the RPD determination that "despite the fact that the Appellant was an observant Muslim, he did not mention any 'other fears or conflicts' relating to his bisexuality" ${ }^{80}$ For the RPD, the appellant "appears to be an observant Muslim," because he took a religious pilgrimage to Saudi Arabia and his wife wore a hijab. ${ }^{81}$ On this information, the RPD concluded, "The claimant's failure to address this apparent discrepancy between his public behaviour and religious beliefs and his alleged personal sexual behaviour" undermined his credibility. ${ }^{82}$ The IRB on appeal disregarded this reasoning: "While the RPD's reasoning does not, of course, call upon any sort of derogatory stereotype regarding bisexuals, the view that someone who is ostensibly religious would either be less likely to engage in sexual activity with the same sex or would necessarily suffer from 'fears or conflicts' is nonetheless a generalization and should be avoided." 83

These examples show that the guidelines are unearthing and undoing stereotypes that have long laced refugee credibility determinations. This is an improvement upon previous practice, but also a clear indication that Canadian refugee institutions are playing a game of catch-up with homonationalist discourses and still have work to do.

\section{Conclusion}

Cultural understandings of queerness common to Canadaa nation-state with a long settler colonial and white supremacist history-inform how the gatekeepers in refugee law evaluate the authenticity of the queerness of refugee claimants of colour, in instances related to personal appearance, community engagement, and relationship with country of reference. The stereotypes identified in appeals and judicial reviews sit at the crossroads of sexual and racial identity, which means that queers of colour especially struggle to enact stereotypically Canadian queerness, and their failure to do so leads to IRBs finding that their claims to queerness lack credibility.

Canada's current legislative regime exacerbates the divide that Puar articulates, between the acceptable queer subject and the terrorist body. Long since Ward and despite the 2017 Chairperson's Guidelines, IRB decision-making contexts have courted stereotype when processing (and rejecting) diverse SOGIE applications on the basis of negative credibility assessments. The turn toward national securitization intensifies the refugee system's homonationalist paradigm. While much of the evidence of this intensification will be difficult to tease apart, given the nature of dog-whistle politicking, we hold that sexual minority claimants of colour are especially vulnerable to the impacts of an aggressively antiterrorist, anti-fraud refugee apparatus, given the ways in which credibility determinations in IRB contexts have operated. The impacts have reverberated for racialized refugee claimants who may struggle to enact the queer expression common in Canada, and may face refoulement as a result. There are also grave implications for the national body politic itself, which through the deployment of homonationalist mechanisms fails to encompass and advance diverse queer representation and struggles to live up to its reputation as a place of tolerance. $^{84}$

We have explored these implications in order to highlight the need for further research into IRB analysis for both subjects who were the focus of our article-LGB folk-and persons with diverse gender identities and expressions. This research is part of the work that will contribute to sustained pressure on IRB adjudicators to adhere to the Chairperson's Guidelines that seek to protect diverse sOGIE refugees from damaging stereotypes and to reduce the lag time between equity seeking politico-legal changes and deeper systemic change.

\section{Notes}

1 We use the term persons (or queers) of colour when referencing a population's encounters in racialized reception contexts, in order to highlight when and how they encounter racialization. We prefer the term racialized persons, to highlight how race is a category historically constructed in reference to systems of power that inferiorize, criminalize, securitize, and exclude.

2 Refugeeness, or the construction and experience of the refugee, is a term used in Marie Lacroix, "Canadian Refugee Policy and the Social Construction of the Refugee Claimant Subjectivity: Understanding Refugeeness," Journal of Refugee Studies 17, no. 2 (2004): 147-66. She means the term to capture the moment of crisis that is the refugee's experience of being in legal limbo in terms of work, family, and the state.

3 The most comprehensive, though not exhaustive, acronym used in Canadian contexts, LGBTQQIAA2, stands for lesbian, 
gay, bisexual, transgender, queer, questioning, intersex, asexual, ally, and 2-spirit. The shorthand for sexualities is $L G B$, or the umbrella term queer. We use both terms interchangeably, along with terms found in legal scholarship: sexual minorities, and (more specifically) refugees with diverse sexual orientations and gender identities and expressions (sOGIE). Homosexual and homosexuality will be used only when referencing historical legal language and some of the work around homonationalism (given the word is contained in the construct).

4 The inspiration for this article stemmed from news coverage of Seidu Mohammed. On Christmas Eve 2016, Mohammed crossed the us/Canada border, losing his fingers to frostbite in the process. He claimed asylum in Canada on the grounds that he could not return to Ghana, his country of origin, because of his bisexual orientation. After the Immigration and Refugee Board of Canada accepted his application for refugee protection, СВС News reported on Mohammed celebrating Pride in June 2017 and appreciating Canadian hospitality. Such feel-good stories have helped solidify Canada's reputation as a safe haven for sexual minorities-a "saviour narrative" reputation we challenge by investigating what asylum seekers might actually face when making refugee claims. See "I'm Finally Home': Frostbitten Asylum Seeker Wins Case to Stay in Canada," Свс News, May 18, 2017, http://www.cbc.ca/news/canada/ manitoba/seidu-mohammed-asylum-seeker-frostbittenrefugee-manitoba-1.4121034.

5 Jasbir Puar, Terrorist Assemblages: Homonationalism in Queer Times (Durham, NC: Duke University Press, 2007), 2.

6 David Murray, Real Queer? Sexual Orientation and Gender Identity Refugees in the Canadian Refugee Apparatus (London: Rowman and Littlefield International, 2016), 5.

7 David Murray, "Real Queer: 'Authentic' LGBT Refugee Claimants and Homonationalism in the Canadian Refugee System," Anthropologica 56, no. 1 (2014): 21.

8 Puar, Terrorist Assemblages, xiii.

9 Puar, Terrorist Assemblages, 19.

10 Canada (AG) v Ward, [1993] 2 SCR 689 [Ward].

11 Protecting Canada's Immigration System Act, SC 2012, c 17 [PCISA].

12 Immigration and Refugee Board of Canada. Guideline 9Proceedings before the IRB Involving Sexual Orientation and Gender Identity and Expression. Guidelines issued by the chairperson pursuant to paragraph 159(1)(h) of the Immigration and Refugee Protection Act [Chairperson's Guidelines].

13 Puar, Terrorist Assemblages, 165.

14 Suzanne Lenon and OmiSoore H. Dryden, "Introduction: Interventions, Iterations, and Interrogations That Disturb the (Homo)Nation," in Disrupting Queer Inclusion: Canadian Homonationalisms and the Politics of Belonging, edited by OmiSoore H. Dryden and Suzanne Lenon, 6-18 (Vancouver: UBC Press, 2015).

15 Sexual citizenship is a term popularized in Brenda Cossman, Sexual Citizens: The Legal and Cultural Regulation of Sex and Belonging (Stanford: Stanford University Press, 2007). See also Gary Kinsman and Patrizia Gentile, The Canadian War on Queers: National Security as Sexual Regulation (Vancouver: UBC Press, 2010).

16 Puar, Terrorist Assemblages, 148.

17 Sara Ahmed, "Problematic Proximities: Or Why Critiques of Gay Imperialism Matter," Feminist Legal Studies 19 (2011): 124.

18 Ahmed, "Problematic Proximities."

19 An objection to our argument-that homonationalism informs IRB credibility assessments-is that credibility assessments are necessary to ferret out fraudulent claims. As an example, СвС News investigators identify similarities among Nigerian refugee claimants filing sexual orientation claims in Canada. They interview Legal Aid Ontario representative Jawad Kassab, who worries that many claims are inauthentic, at the coaching of refugee lawyers. The Nigerian government passing anti-LGBTQ policy affords claimants an opportunity to seek refuge on sexual minority grounds, even if they are not queer. To quote Kassab, “There's certain patterns that when you look at them ... you begin to wonder about the plausibility and begin to suspect that maybe some of these claims are fabricated" (Anita Elash, Diana Swain, and Tara Carman, "60-70\% of Nigerian Claims Made in Ontario since April Cited Persecution Based on Sexual Orientation," свC News, November 10, 2017, http://www.cbc.ca/news/canada/nigeria-refugeehomosexuality-immigration-1.4390144). In this article we will not re-produce the logics of IRB decisions by questioning the validity of claims. Instead, we are concerned with what suspicion of claims does-the work it does to produce narrow, race-inflected understandings of queerness. Indeed, the patterns emerging across Nigerian sexual minority claims point to the problem that claimantswhether they are actually queer or not-are performing a kind of queerness they have learned is acceptable to Immigration and Refugee Boards.

20 Jasbir Puar, "Citation and Censorship: The Politics of Talking about the Sexual Politics of Israel," Feminist Legal Studies 19 (2011): 133-42.

21 Lacroix, "Canadian Refugee Policy," 163.

22 Kinsman and Gentile, Canadian War on Queers.

23 Ahmed, "Problematic Proximities," 125.

24 "Plausibility findings cannot be made on the basis of stereotypical attitudes or projected behaviours that is unsupported by the evidence" in Dosmakova $v$ Canada (Citizenship and Immigration), $2007 \mathrm{FC} 1357$ at para 12 [Dosmakova].

25 Rohan Sajnani, Envisioning Global LGBT Human Rights: The Impact of Canada's New Immigration Regime (Toronto: York University, 2014), 12.

26 Ahmed, "Problematic Proximities," 127.

27 We showcase how homonationalism bears out in legal discourse following the 2001 catalyst that brought terrorism into public consciousness. The hearings selected as evidence in section 3 took place in the post-Ward era, but do 
not date as far back as 1993; rather, they took place after 2001, in the ramping up of the securitized state. Section 4 focuses on hearings clustered around Bill C-31, which connected securitization to refugee credibility standards.

28 Refugee rights were first formally recognized under international law in a multilateral treaty, the 1951 Convention Relating to the Status of Refugees (July 28, 1951, UN Ts No 2545 (entered into force April 22, 1954). The definition provided in the convention is the cornerstone to Canadian refugee law, reiterated in the Immigration and Refugee Protection Act (RSC 2001, c 207, s 96). This definition requires that refugees have a well-founded fear of persecution based on their race, religion, nationality, membership to a particular social group, or political opinion; that they be outside their country of nationality and unable to return, or unwilling for fear of persecution.

29 [1991] CRDD No. 1140.

30 Ward. Patrick Francis Ward feared persecution and thus sought refugee status in Canada, because he deserted an Irish terrorist organization after a crisis of conscience.

31 Ward, 739d-e.

32 Ward, 739g. Of note, socio-legal scholars critical of the Ward decision contest the location of sexual minorities in Justice La Forest's first category, wherein groups are defined by an innate or immutable characteristic. See Nicole LaViolette, "The Immutable Refugees: Sexual Orientation in Canada (A.G.) v. Ward," University of Toronto Faculty of Law Review 55, no. 1 (1997): 1-44; LaViolette argues that sexual orientation should qualify as a social group under refugee law for being a social identity that persecutors assume is socially and politically inferior. See also Sean Rehaag, "Patrolling the Borders of Sexual Orientation: Bisexual Refugee Claims in Canada," McGill Law Journal 53 (2008): 59-102; Rehaag illustrates how the sCC interpretation of sexual orientation has posed complications for bisexual refugee claimants.

33 LaViolette, "Immutable Refugees."

34 Nicholas Hersh, "Challenges to Assessing Same-Sex Relationships under Refugee Law," McGill Law Journal 6o, no. 3 (2015): 527.

35 Sharalyn Jordan and Chris Morrissey, “On What Grounds?' LGBT Asylum Claims in Canada," Sexual Orientation and Gender Identity and the Protection of Forced Migrants 42 (n.d.): 14.

36 un High Commissioner for Refugees, Guidelines on International Protection No. 9: Claims to Refugee Status Based on Sexual Orientation and/or Gender Identity within the Context of Article 1.A(2) of the 1951 Convention and/or Its 1967 Protocol Relating to the Status of Refugees (October 23, 2012) HCR/GIP/12/o1, http://www.refworld.org/docid/50348afc2 .html.

$372005 \mathrm{FC} 1233$ at para 12.

382005 FC 1233 at paras 3-5.

392005 FC 1233 at para 7.

402005 FC 1233 at para 15.
412005 FC 1233 at para.34.

42 Dosmakova at para 11.

43 Immigration and Refugee Protection Act, RSC 2001, c 207 [IRPA].

44 Francois Crepeau and Delphine Nakache, "Controlling Irregular Migration in Canada: Reconciling Security Concerns with Human Rights Protection," IRPP Choices 12, no. 1 (2006): 14. See also Baljit Nagra, Securitized Citizens: Canadian Muslims' Experiences of Race Relations and Identity Formation Post-9/11 (Toronto: University of Toronto Press, 2017).

45 IRPA at $\operatorname{art} 3(2)(\mathrm{g})(\mathrm{h})$.

46 PCISA.

47 Immigration and Refugee Board of Canada, 2012-13 Part III-Departmental Performance Report (Ottawa: IRB, 2013), https://irb-cisr.gc.ca/en/reports-publications/planningperformance/Pages/DprRmr1213Part111.aspx https://www .dailyxtra.com/analysis-unpacking-the-latest-refugeereform-bill-32794 .

48 Dale Smith, "Analysis: Unpacking the Latest Refugee Reform Bill," Xtra, February 28, 2012, https://www.dailyxtra.com/ analysis-unpacking-the-latest-refugee-reform-bill-32794.

49 PCISA at Summary.

50 Sajnani, Envisioning Global LGBT Human Rights, 13.

51 Emily Bates, Jennifer Bond, and David Wiseman, "Troubling Signs: Mapping Access to Justice in Canada's Refugee System Reform," Ottawa Law Review 47, no. 1 (2016): 1-72.

52 Jordan and Morrissey, "On What Grounds?" 15.

53 Sajnani, Envisioning Global LGBT Human Rights.

54 Kathryn Trevenen and Alexa Degagne, "Homonationalism at the Border and in the Streets: Organizing against Exclusion and Incorporation," in Dryden and Lenon, Disrupting Queer Inclusion, 106.

55 Trevenen and Degagne, "Homonationalism at the Border," $105-6$.

56 Shanti Fernando and Jen Rinaldi, "Seeking Equity: Disrupting Exclusionary Immigration Frameworks," Canadian Ethnic Studies 49, no. 3 (2017): 7-26.

57 Ahmed, "Problematic Proximities."

582011 FC 1493 at para 31.

$592011 \mathrm{FC} 1493$ at para 6.

$602011 \mathrm{FC} 1493$ at para 7.

$612011 \mathrm{FC} 1493$ at para 29.

$622011 \mathrm{FC} 1493$ at para 18.

$632011 \mathrm{FC} 1493$ at para 33.

642013 FC 893.

652013 FC 893 at para 4.

$662013 \mathrm{FC} 893$ at para 33.

672013 FC 893 at para 45.

68 Chairperson's Guidelines, 1.1.

69 Chairperson's Guidelines, 3.1.

70 Chairperson's Guidelines, 3.5; 8.5.2.1.

71 Chairperson's Guidelines, 6.1.

72 Chairperson's Guidelines, 7.2.3.

73 Chairperson's Guidelines, 7.4.1. 
74 Chairperson's Guidelines, 7.6.1.

$75 X(R e),(2017)$ CanLII 142605 at para 3.

$76 X(R e),(2017)$ CanLII 142605 at para 19.

77 Hersh, "Challenges to Assessing."

$78 X(R e),(2017)$ CanLII 143151.

$79 X(R e),(2017)$ CanLII 143151 at para 14.

$80 X(R e),(2017)$ CanLII 143151 at para 9.

$81 X(R e),(2017)$ CanLII 143151 at para 20.

$82 X(R e),(2017)$ CanLII 143151 at para 20.

$83 X(R e),(2017)$ CanLII 143151 at para 22.
84 Fernando and Rinaldi, "Seeking Equity."

Jen Rinaldi is an assistant professor at the University of Ontario Institute of Technology. The author may be contacted at Jen. Rinaldi@uoit.ca.

Shanti Fernando is an associate professor at the University of Ontario Institute of Technology. The author may be contacted atShanti.Fernando@uoit.ca. 